\title{
GIS Based Inverse Distance Weighting Spatial Interpolation Technique for Fluoride Occurrence in Ground Water
}

\author{
M. Arif ${ }^{*}$, J. Hussain'², I. Hussain ${ }^{3}$, S. Kumar ${ }^{4}$, G. Bhati ${ }^{4}$ \\ ${ }^{1}$ Department of Chemistry, Banasthali University, Niwai, District-Tonk, India \\ ${ }^{2}$ National River Water Quality Laboratory, Central Water Commission, New Delhi, India \\ ${ }^{3}$ Public Health Engineering Department (PHED) Laboratory, Bhilwara, India \\ ${ }^{4}$ Department of Space, Regional Remote Sensing Centre (West), NRSC/ISRO, Jodhpur, India \\ Email: ${ }^{*}$ r.arifmohammed@gmail.com
}

Received 9 April 2014; revised 19 May 2014; accepted 9 July 2014

Copyright (C) 2014 by authors and OALib.

This work is licensed under the Creative Commons Attribution International License (CC BY).

http://creativecommons.org/licenses/by/4.0/

(c) (i) Open Access

\begin{abstract}
This study was conducted to evaluate fluoride contamination in ground water of the central part of Nagaur district where ground water is the main source of drinking as well as irrigation. Samples from hand pumps and tube wells of forty four stations were analyzed during the summer session with the help of standard methods of APHA. The analytical results show that eleven ground water samples are unfit for drinking purpose. A map has been prepared using an inverse distance weighting method which shows the fluoride concentration in the study area. The maximum concentration was recorded in the Sirsi village while the minimum was found in Sabalpura.
\end{abstract}

\section{Keywords}

Fluoride, Groundwater, Central Part, Nagaur, Rajasthan

Subject Areas: Environmental Sciences, Hydrology

\section{Introduction}

Water is very vital in nature and can be a limiting resource for men and other living beings. Without a well functioning water supply, it is difficult to imagine a productive human activity be it agriculture or livestock. The quality of water is of almost importance of quantity in any water supply planning. Water quality is influenced by natural and anthropogenic effects including local climate, geology and irrigation practices. In the world, around 200 million people from 25 nations have greater health risks, with high fluoride in the drinking water [1]. Vari*Corresponding author.

How to cite this paper: Arif, M., Hussain, J., Hussain, I., Kumar, S. and Bhati, G. (2014) GIS Based Inverse Distance Weighting Spatial Interpolation Technique for Fluoride Occurrence in Ground Water. Open Access Library Journal, 1: e546. http://dx.doi.org/10.4236/oalib.1100546 
ous workers in our country have carried out extensive studies on water quality with reference to the fluoride concentration [2]-[8].

In Indian continent the higher concentration of $\mathrm{F}^{-}$in groundwater is associated with igneous and metamorphic rocks. Some anthropogenic activities such as use of phosphatic fertilizers, pesticides and sewage and sludges, depletion of groundwater table etc., for agriculture has also been indicated to cause an increase in $\mathrm{F}^{-}$concentration in groundwater [9] [10]. According to WHO (2006), the permissible limit for $\mathrm{F}^{-}$in drinking water is 1.5 $\mu \mathrm{g} / \mathrm{ml}$. In India almost 60 - 65 million people drink fluoride contaminated groundwater and the number affected by fluorosis is estimated at 2.5 to 3 million in many States, especially, Andhra Pradesh, Bihar, Gujarat, Madhya Pradesh, Punjab, Rajasthan, Tamil Nadu and Uttar Pradesh [11]-[20]. The first case of endemic fluorosis in the country was reported as long as 1937 in the Prakasam District (erstwhile Guntur District), Andhra Pradesh [21]. WHO (2004) has laid down a limit of $1.5 \mathrm{mg} / \mathrm{l}$ fluoride in drinking water [22]. This maximum limit protects tooth decay and enhances proper bone growth. In India, safe limit of fluoride in potable water is between 0.6 and $1.2 \mathrm{mg} / \mathrm{l}$ [23]. Lower limit of fluoride $(<0.6 \mathrm{mg} / \mathrm{l})$ than that of the prescribed limit $(0.6 \mathrm{mg} / \mathrm{l})$ causes dental caries, while the higher limit of fluoride ( $>1.2 \mathrm{mg} / \mathrm{l})$ than those of the recommended limit $(1.2 \mathrm{mg} / \mathrm{l})$ results in fluorosis. Rajasthan is the largest state in India is having $342,239 \mathrm{~km}^{2}$ area with a relatively low population density, i.e., 165 persons per square kilometer. According to physiographies divisions, the north and western part of the state is under the Great Plain of north India, while south and middle as well as eastern part is classified under the Peninsular Plateau. In the state, Thar Desert occupies about $61 \%$ of the total area. Groundwater is a major source for drinking and domestic and irrigation purpose [24]. Nagaur District is located at latitude $26^{\circ} 25^{\prime}$ to $27^{\circ} 40^{\prime} \mathrm{N}$ and longitude $73^{\circ} 18^{\prime}$ to $75^{\circ} 15^{\prime}$ E. Its average elevation is about $300 \mathrm{~m}$, ranging below $250 \mathrm{~m}$ in the south and $640 \mathrm{~m}$ in the north. There are 1396 habitations in the district. The main lithological units include gneisses, schists, granites, quartzites, phyllites, and limestones belonging to the Bhilwara and Delhi Supergroup of rocks of Archaean and Proterozoic ages, respectively. Although groundwater occurs mainly under water table condition in all the formations, the quaternary alluvium forms good aquifers in Nagaur District. In the hard rock terrain, the occurrence and movement of groundwater are controlled by secondary porosity such as fractures, fissures, joints, foliation, etc. A bibliographic survey has also shown that no studies have been undertaken in the district for assessment of the $\mathrm{F}^{-}$concentration in its groundwater. This study was, therefore, undertaken to investigate the quality of underground drinking water of the central part of Nagaur district of Rajasthan, India in respect of $\mathrm{F}^{-}$concentration.

These minerals are commonly associated with the country rocks through which the ground water percolates under variable temperature conditions. Besides these minerals, alkali rocks, hydrothermal solutions may also contribute to higher concentration of fluoride in groundwater. Robinson and Edington (1946) reported that the main source of fluoride in ordinary soil consists of clay minerals. The weathering and leaching process, mainly by moving and percolating water, play an important role in the incidence of fluoride in groundwater [25]. When fluoride rich minerals, which are present in rocks and soil, come in contact with water of high alkalinity; they release fluoride into groundwater through hydrolysis replacing hydroxyl $(\mathrm{OH})$ ion. The degree of wreathing and leachable fluoride in a terrain is more important in deciding the fluoride bearing minerals in the bulk rocks or soil. Due to weathering of rocks the Ca-Mg/carbonate concentration which form in arid and semi arid areas appears to be good sink for the fluoride ion [26]. While fluoride is present in air, water and food, the most common way it enters the food chain is via drinking water.

\section{Material and Method}

Groundwater samples of 44 habitations located in the Nawa block of Nagaur District were collected in precleaned polyethylene bottles following standard sampling techniques. The fluoride concentration in water was determined electrochemically, using fluoride ion selective electrode [27]. This method is applicable to the measurement of fluoride in drinking water in the concentration range of $0.01-1000 \mathrm{mg} / \mathrm{l}$. The electrode used to be an Orion fluoride electrode, coupled to an Orion electrometer. Standards fluoride solutions $(0.1-10 \mathrm{mg} / \mathrm{l})$ were prepared from a stock solution $(100 \mathrm{mg} / \mathrm{l})$ of sodium fluoride. As per experimental requirement, $1 \mathrm{ml}$ of total ionic strength adjusting buffer grade III (TISAB III) was added in $10 \mathrm{ml}$ of sample. The ion meter was calibrated for a slop of $-59.2 \pm 2$. The composition of TISAB solution was $385.4 \mathrm{~g}$ ammonium acetate, $17.3 \mathrm{~g}$ of cyclohexylene diamine tetraacetic acid, and $234 \mathrm{ml}$ of concentrate hydrochloric acid per liter. All the experiments were carried out in triplicate and the results were found reproducible with $\pm 2 \%$ error. 


\subsection{Preparation of TISAB- III}

Take $250 \mathrm{ml}$ de-ionized water and add $234 \mathrm{ml}$ of concentrated hydrochloric acid. Add $385.4 \mathrm{gm}$ of Ammonium acetate. Add $17.3 \mathrm{gm}$ of 1, 2-cyclohexylene-diaminetetraacetic (CDTA). Stir to dissolve and cool at room temperature. Make it up to $1000 \mathrm{ml}$.

\subsection{Procedure}

1) Calibration of instrument: Prepare a series of standards over the appropriate concentration range $(0.1 \mathrm{mg} / \mathrm{l}$, $1.0 \mathrm{mg} / \mathrm{l}$ and $10.0 \mathrm{mg} / \mathrm{l}$ ) Calibrate the instrument to obtain $-59.2 \pm 2 \mathrm{mv}$ slop.

2) Take $10 \mathrm{ml}$ sample add $1 \mathrm{ml}$ of TISAB III and measure fluoride concentration.

\subsection{Spatial Distribution of Fluoride Using Inverse Distance Weighted Method}

Geographic Information System (GIS) is a computerized data based system for capture, storage, retrieval, analysis and display of spatial data. GIS is a general purpose technology for handling geographic data in digital form, and satisfying the following specific needs, among others. The Inverse distance weighted (IDW) interpolation explicitly implements the assumption that things that are close to one another are more alike than those that are farther apart. To predict a value for any unmeasured location, IDW uses the measured values surrounding the prediction location. The measured values closest to the prediction location have more influence on the predicted value than those farther away. IDW assumes that each measured point has a local influence that diminishes with distance. It gives greater weights to points closest to the prediction location, and the weights diminish as a function of distance, hence the name Inverse distance weighted

\section{Result}

Fluoride concentration in groundwater of 44 habitations of Nawa block was examined. All the habitations were categorized according to following concentration range (Table 1):

Category I-Fluoride concentration below $1.0 \mathrm{mg} / \mathrm{l}$;

Category II—Fluoride concentration between 1.0 and $1.5 \mathrm{mg} / \mathrm{l}$;

Category III—Fluoride concentration between 1.5 and $3.0 \mathrm{mg} / \mathrm{l}$;

Category IV-Fluoride concentration between 3.0 and $5.0 \mathrm{mg} / \mathrm{l}$; and

Category V-Fluoride concentration above $5.0 \mathrm{mg} / \mathrm{l}$.

The distribution of fluoride in the groundwater of Nawa block is shown in Figure 1. Figure 2 shows the no. of villages and their fluoride concentration range as per divided categorization. Fluoride concentration ranges from 0.4 to $5.9 \mathrm{mg} / \mathrm{l}$. The minimum concentration was recorded in the Sablpura village while maximum concentration was recorded from Sirsi village $(5.9 \mathrm{mg} / \mathrm{l})$. It is clear from Figure 2 that the maximum villages belong to the concentration of below $1.0 \mathrm{mg} / \mathrm{L}$. The present investigation reveals that 19 habitations (43\%) fall in category I .in which fluoride concentration is below $1.0 \mathrm{mg} / \mathrm{l}$, a maximum desirable limit of standards for drinking water recommended by who. There is no possibility of fluorosis in these habitations because this concentration of fluoride is beneficial for calcification of dental enamel especially for children below 10 years of age. Once fluoride is incorporated into teeth, it reduces the solubility of the enamel under acidic conditions and thereby provides protection against dental carries. Out of 44 habitations of Nawa block, 14 habitations (32\%) have fluoride concentration between 1.0 and $1.5 \mathrm{mg} / \mathrm{l}$ and fall in category II. The maximum permissible limit of fluoride in standard for drinking water is $1.5 \mathrm{mg} / \mathrm{l}$ who. In 32\% population of these habitations, fluoride intake through drinking water is more than $4 \mathrm{mg} /$ day in an individual. Therefore, an incidence of first and second degree dental fluorosis is possible in local residents of these habitations. About $17 \%$ of the population of 4 habitations (16\%) consumes water with fluoride concentration between 1.5 and $3.0 \mathrm{mg} / \mathrm{l}$, which is above the maximum permissible limit as recommended by who. Therefore, dental fluorosis is common in these habitations. At this concentration, the teeth lose their shiny appearance and chalky black, gray, or white patches develop known as mottled enamel [28]. In four habitations (9\%), fluoride concentration in groundwater is above $3.0 \mathrm{mg} / \mathrm{l}$ and below $5.0 \mathrm{mg} / \mathrm{l}$, and this fall in category IV. The intake of fluoride per day by an adult in these habitations is very high. About $6 \%$ population of these habitations may have all degrees of dental fluorosis (mild, moderate, moderately severe, and severe fluorosis) including skeletal fluorosis after 30 years of age. However, the probability of second stage skeletal fluorosis age may be more common after the age of 45 [29]. In the entire survey, Sirsi was the only vil- 
Table 1. Fluoride categorization of villages of Nawa tehsil.

\begin{tabular}{|c|c|c|c|c|c|c|c|c|c|}
\hline \multicolumn{2}{|c|}{$\begin{array}{c}\text { Category I } \\
\text { (Below } 1.0 \mathrm{mg} / \mathrm{l})\end{array}$} & \multicolumn{2}{|c|}{$\begin{array}{c}\text { Category II } \\
\text { (Between } 1.0 \text { and } 1.5 \mathrm{mg} / \mathrm{l} \text { ) }\end{array}$} & \multicolumn{2}{|c|}{$\begin{array}{c}\text { Category III } \\
\text { (Between } 1.5 \text { and } 3.0 \mathrm{mg} / \mathrm{l} \text { ) }\end{array}$} & \multicolumn{2}{|c|}{$\begin{array}{c}\text { Category IV } \\
\text { (Between } 3.0 \text { and } 5.0 \mathrm{mg} / \mathrm{l} \text { ) }\end{array}$} & \multicolumn{2}{|c|}{$\begin{array}{c}\text { Category V } \\
\text { (Above } 5.0 \mathrm{mg} / \mathrm{l} \text { ) }\end{array}$} \\
\hline Chawandiya & 0.8 & Lalas & 1.2 & Rooppura Torda & 2.4 & Piprali & 4.2 & Sirsi & 5.9 \\
\hline Adaksar & 0.9 & Parewadi & 1.4 & Shyamgarh & 2.4 & Thikariya Khurd & 4.4 & & \\
\hline Todas & 0.9 & Kotra & 1.2 & Kooni & 2.2 & Prempura & 3.0 & & \\
\hline Charanwas & 0.6 & Jiliya & 1.4 & Mindha & 1.5 & Padampura & 4.0 & & \\
\hline Nalot & 0.7 & Rasal & 1.3 & Karkeri & 2.4 & Ghandi Gram & 3.3 & & \\
\hline Chitawa & 0.8 & Panchwa & 1.1 & & & & & & \\
\hline Sabalpura & 0.4 & Rewasa & 1.4 & & & & & & \\
\hline Aspura & 0.8 & Lichana & 1.1 & & & & & & \\
\hline Bhanwata & 0.7 & Panchota & 1.4 & & & & & & \\
\hline Kukanwali & 0.9 & Mandawara & 1.2 & & & & & & \\
\hline Nagwara & 0.8 & Kasari & 1.1 & & & & & & \\
\hline Rajliya & 0.6 & Govindi & 1.2 & & & & & & \\
\hline Nuwana & 0.5 & Bhatipura & 1.1 & & & & & & \\
\hline Gogor & 0.7 & Deoli & 1.2 & & & & & & \\
\hline Maroth & 0.8 & & & & & & & & \\
\hline Jeenwar & 0.7 & & & & & & & & \\
\hline Ulana & 0.6 & & & & & & & & \\
\hline Bawali Gurha & 0.7 & & & & & & & & \\
\hline Nanana & 0.9 & & & & & & & & \\
\hline
\end{tabular}

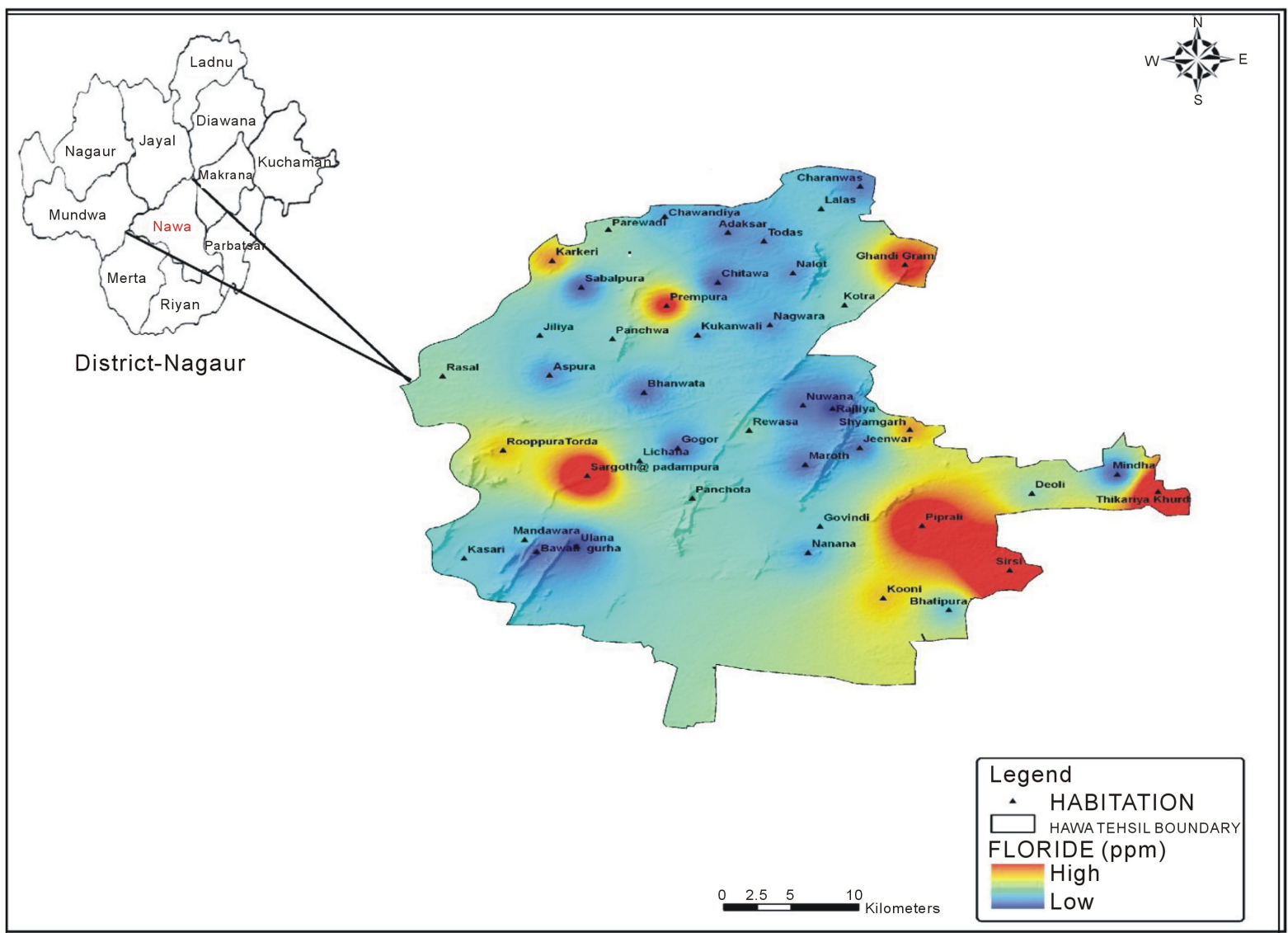

Figure 1. Fluoride distribution map of Nawa Tehsil using inverse distance weighting method. 


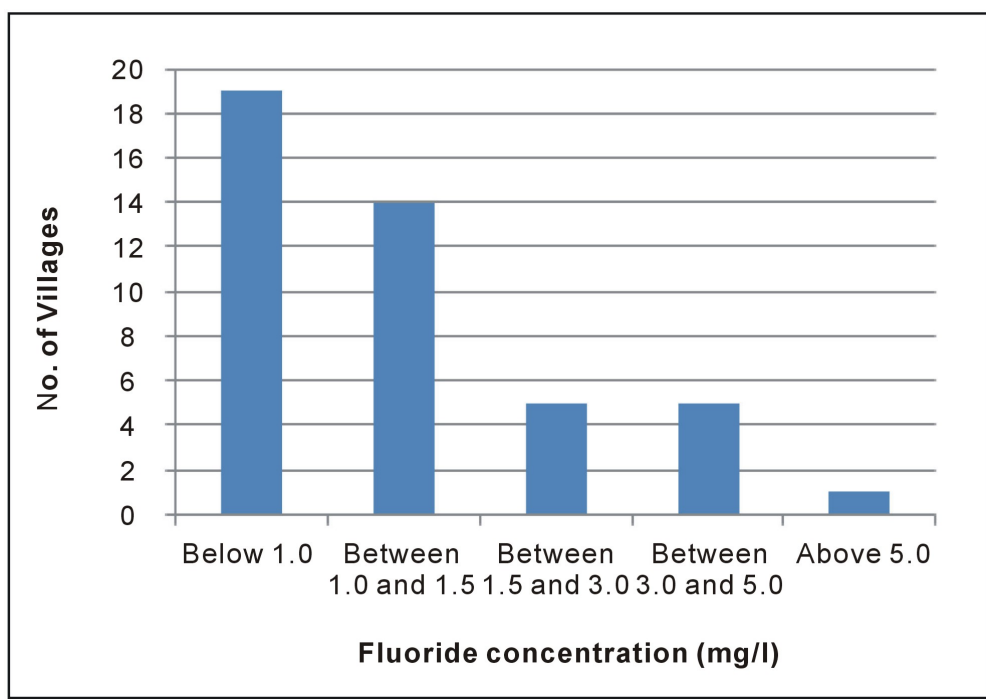

Figure 2. Categorization of villages as per their fluoride concentration range.

lage that falls in category $\mathrm{V}$, which contributes $1 \%$ population of Nawa block. In this village, fluoride concentration is above $5.0 \mathrm{mg} / \mathrm{l}$, which may result in all types of fluorosis among inhabitants. In the second clinical stage, the affected persons may have pain in bones, which causes further calcification in ligaments. A detailed survey of health hazards particularly fluorosis-induced symptoms and empirical data on affected population are required in Nawa.

\section{Conclusions}

The lack of resources and low-cost efficient technology acceptable to the affected populations restrict the development of an effective fluoride and fluorosis control and prevention program in developing countries.

- Provisions of alternative water sources such as the delivery of water from low fluoride sources have also been considered for fluorosis prevention strategies.

- Construction of piped networks for the purpose of potable water.

- It is suggested that the sources of municipal water supply must be established in a region where adequate levels of fluoride have been observed.

- One more way to avoid excessive fluoride intake is rainwater harvesting. The dilution of high fluoride water with rainwater will make small amount of rainwater to last long.

- A public health programme should be designed by taking into account all the fluoride sources, including dietary fluoride.

\section{References}

[1] Ayoob, S. and Gupta, A.K. (2006) Fluoride in Drinking Water: A Review on the Status and Stress Effects. Critical reviews in Environmental Science and Technology, 36, 433-487. http://dx.doi.org/10.1080/10643380600678112

[2] Arif, M., Hussain, J., Hussain, I. and Neyol, S. (2011) Fluoride Contamination of Ground Water of Merta Block in Nagaur District, Rajasthan, India. The Conference of Advance in Environmental Chemistry (AEC), Aizwal, 146-148.

[3] Arif, M., Hussain, I., Hussain, J., Sharma, S. and Kumar, S. (2012) Fluoride in the Drinking Water of Nagaur Tehsil of Nagaur District, Rajasthan, India. Bulletin of Environmental Contamination and Toxicology, 88, 870-875. http://dx.doi.org/10.1007/s00128-012-0572-4

[4] Hussain, J., Sharma, K.C. and Hussain, I. (2005) Fluoride Distribution in Groundwater of Banera Tehsil in Bhilwara District, Rajasthan. Asian Journal of Chemistry, 17, 457-461.

[5] Hussain, J., Shrama, K.C., Arif, M. and Hussain, I. (2007) Fluoride Distribution and Modelling Using Best Subset Procedure in Nagour District of Central Rajasthan, India. The 27th Conference of the International Society for Fluoride Research (ISFR XXVII), Beijing.

[6] Hussain, I., Arif, M. and Hussain, J. (2011) Fluoride Contamination in Drinking Water in Rural Habitations of Central 
Rajasthan, India. Environmental Monitoring and Assessment, 184, 5151-5158. http://dx.doi.org/10.1007/s10661-011-2329-7

[7] Sharma, K.C., Arif, M., Hussain, I. and Hussain, J. (2007) Observation on Fluoride Contamination in Groundwater of District Bhilwara, Rajasthan and a Proposal for a Low Cost Defluoridation Technique. The 27th Conference of the International Society for Fluoride Research (ISFR XXVII), Beijing.

[8] Choubisa S.L., Choubisa L. and Choubisa D.K. (2001) Endemic Fluorosis in Rajasthan. Indian Journal of Environmental Health, 43, 177-189.

[9] EPA (1997) Public Health Global for Fluoride in Drinking Water. Pesticide and Environmental Toxicology. Section Office of Environmental Health Hazard Assessment, California Environmental Protection Agency.

[10] Ramanaiah, S.V., Venkatamohan, S., Rajkumar, B. and Sarma, P.N. (2006) Monitoring of Fluoride Concentration in Groundwater of Prakasham District in India: Correlation with Physico-Chemical Parameters. Journal of Environmental Science and Engineering, 48, 129-134.

[11] WHO (2006) Fluoride in Drinking Water. IWA Publishing, London, 144.

[12] Athavale, R.N. and R.K. Das (1999) Beware! Fluorosis Is Zeroing in on You. Down to Earth, 8, 24-25.

[13] Susheela, A.K. (1999) Fluorosis Management Programme in India. Current Science, 77, 1250-1256.

[14] Chakraborti, D., Chanda, C.R., Samanta, G., Chowdhury, U.K., Mukherjel, S.C. and Pal, A.B. (2000) Fluorosis in Assam, India. Current Science, 78, 1421-1423.

[15] Muralidharan, D., Nair, A.P. and Satyanarayana, U. (2002) Fluoride in Shallow Aquifers in Rajgarh Tehsil of Churu District, Rajasthan-An Arid Environment. Current Science, 83, 699-702.

[16] Pillai, K.S. and Stanley, V.A. (2002) Implications of Fluoride-An Endless Uncertainty. Journal of Environmental Biology, 23, 81-97.

[17] Arif, M., Joshi, S. and Kumar, S. (2012) A Study of Fluoride Contaminated Ground Water in Uniara Tehsil, DistrictTonk, Rajasthan, India. India Water Week.

[18] Arif, M., Hussain, J., Hussain, I. and Kumar, S. (2013) An Assessment of Fluoride Concentration in Groundwater and Risk on Health of North Part of Nagaur District, Rajasthan, India. World Applied Sciences Journal, 24, 146-153.

[19] Arif, M., Hussain, J., Hussain, I. and Kumar, S. (2013) An Investigation of Fluoride Distribution in Ladnu Block of Nagaur District, Central Rajasthan. World Applied Sciences Journal, 26, 1610-1616.

[20] Arif, M., Yadav, B.S. and Garg, A. (2013) An Investigation of Fluoride Concentration in Drinking Water of Sanganer Tehsil, Jaipur District, Rajasthan, India and Defluoridation from Plant Material. EQA-Environmental Quality, 12, 2329.

[21] Shortt, H.E., Mcrobert, G.R., Barnard, T.W. and Mannadinayer, A.S. (1937) Endemic Fluorosis in Madras Presidency, India. Indian Journal of Medical Research, 25, 553-561.

[22] WHO (2004) Guidelines for Drinking Water Quality. World Health Organization, Geneva, 515.

[23] BIS (2003) Indian Standard Specifications for Drinking Water. Bureau of Indian Standards, New Delhi, India: IS: 10500, 10.

[24] Census (2001) District Nagaur, Rajasthan, Government of Rajasthan.

[25] Robinson, W.O. and Edington, G. (1946) Fluorine in Soils. Soil Science, 61, 341-353. http://dx.doi.org/10.1097/00010694-194605000-00001

[26] Jacks, G., Bhattacharya, P., Chaudhary, V. and Singh, K.P. (2005) Controls on the Genesis of High-Fluoride Ground Waters in India. Applied Geochemistry, 20, 221-228. http://dx.doi.org/10.1016/j.apgeochem.2004.07.002

[27] APHA (1991) Standard Methods for the Examination of Water and Wastewater. 17th Edition, American Public Health Association, Washington DC.

[28] Dean, H.T. (1942) The Investigation of Physiological Effects by the Epidemiological Method. American Association for the Advancement of Science, 19, 23-33.

[29] Olsson, B. (1979) Dental Finding in High Fluoride Areas. Epidemiology, 7, 51-56. 